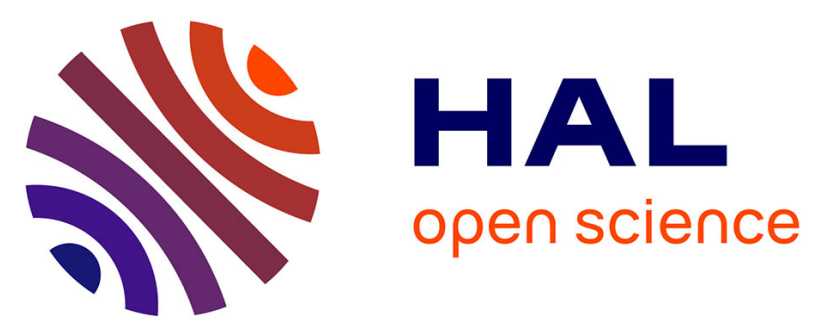

\title{
The School Environment and its Relation with the Quality of Teaching Physical Education
}

M. Bensabeur, H.M. Benkazdali, H. Benssikadour, M. Sebbane, A. Laroua, A. Belkadi, O. Benbernou, Jacques Gleyse

\section{- To cite this version:}

M. Bensabeur, H.M. Benkazdali, H. Benssikadour, M. Sebbane, A. Laroua, et al.. The School Environment and its Relation with the Quality of Teaching Physical Education. European Journal of Physical Education and Sport Science , 2015, 9 (3), pp.130-136. 10.13187/ejpe.2015.9.130 . hal-03330235

\section{HAL Id: hal-03330235 \\ https://hal.science/hal-03330235}

Submitted on 31 Aug 2021

HAL is a multi-disciplinary open access archive for the deposit and dissemination of scientific research documents, whether they are published or not. The documents may come from teaching and research institutions in France or abroad, or from public or private research centers.
L'archive ouverte pluridisciplinaire HAL, est destinée au dépôt et à la diffusion de documents scientifiques de niveau recherche, publiés ou non, émanant des établissements d'enseignement et de recherche français ou étrangers, des laboratoires publics ou privés.

\section{(1)(1) $\$(0)$}

Distributed under a Creative Commons Attribution - NonCommercial - ShareAlikel 4.0 
Copyright (c) 2015 by Academic Publishing House Researcher

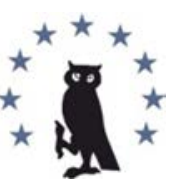

Published in the Russian Federation

European J ournal of Physical Education and Sport

Has been issued since 2013.

ISSN: 2310-0133

Vol. 9, Is. 3, pp. 130-136, 2015

DOI: $10.13187 /$ ejpe.2015.9.130

www.ejournal7.com

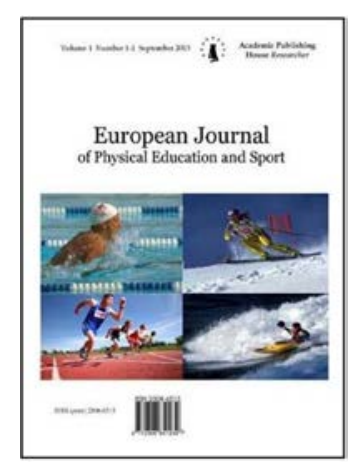

\title{
Articles and Statements
}

\section{The School Environment and its Relation with the Quality of Teaching Physical Education}

\author{
${ }^{1} \mathrm{M}$. Bensabeur \\ ${ }^{1}$ H.M. Benkazdali \\ 2 H. Benssikadour \\ ${ }^{2} \mathrm{M}$. Sebbane \\ ${ }^{2}$ A. Laroua \\ ${ }^{1}$ A. Belkadi \\ ${ }^{1} \mathrm{O}$. Benbernou \\ ${ }^{3} \mathrm{~J}$. Gleyse
}

\begin{abstract}
${ }^{1}$ Laboratory for Optimising Research Programmes on Physical and Sports Activities, Algeria
2 Laboratory of Human Movement and Sciences

Institute for Physical and Sports Education, University of Mostaganem, Algeria

${ }^{3}$ Laboratory for Interdisciplinary Research in Didactic, Education and Training (LIRDEF), E.A. 3749. Doctoral School 58.

University of Montpellier \& University Paul Valéry, Montpellier, France
\end{abstract}

\begin{abstract}
This study aims to explore the nature of the relationship between the quality of education of the PE and the school environment that revolves around the Sports and Physical Education lesson in high schools of the province of Mostaganem (Algeria). To achieve the objectives of this study, two questionnaires were designed. The first on the school environment and the second on the quality of education. A sample of 71 teachers spread across all high schools in the province of Mostaganem voluntarily took part in this study. The results showed a significant effect between the school environment and the quality of teaching physical education. This result allows to predict the quality of the teaching of physical education in high school requires a supportive school environment to meet the expectations and requirements of the discipline.

Keywords: school environment, quality of education, physical education.

\section{Introduction}

Algerian Educational system have known encouraging reforms beginning of the last decade in order to recognize the deficiencies caused the low level of education, these reforms were to update and accelerate the learning process quality to advance education forward, which dealt with the educational system as a whole amendment and development components, and ran it to focus on learner in basis as the educational process axis, and the professor who is one of the most prominent elements in the educational success of the system, as well as the provision of facilities and equipment pedagogical and means necessary for this operation, but despite these reforms, which touched into the educational system and the efforts being made in the field of education in general, and the field physical education, in particular, the achievement of the quality of teaching
\end{abstract}


physical education of the teacher in the present situation is still far away, the follower of the case of physical education notes that it do not achieve all the goals that was written for her, and felt from the outset that there is a contradiction in the configuration between philosophy of what is required to achieve and what is present, and this is what we have observed through the field internship we've made in our academic courses and our friction with professors of physical education and sports at the level of some of the high schools on the one hand, and on the other hand the direct personal stating note of the researcher to some high schools in Mostaganem Province, shown that the school environment material which embraces the subject of physical education and sports are still immune to developments in education, which calls into question the extent to which the quality of teaching physical education of the professor under these physical school environment, by virtue of the quality of teaching requires the actual application of the approach competencies in the field and activating the means of technology and employ modern methods and teaching methods fit with the reality of school materials.

Faced with this conflict between what is needed and what is found, we will try through this research addressed to a set of principles and rules in modern education, because we realize that the process of teaching the physical education success coupled with the extent of the teaching quality of the professor through the possession of a set of competencies and gestures professional that qualify for it, and its interaction with other key factors which are the program and pupils and physical environment, including content of the sports fields pedagogical and means necessary for the Activity of physical education and sports exercise, and all these factors interfere together to influence each other share on the quality of the teaching of this article, positively or negatively, and We have been asking the following questions:

1. What level of teaching physical education and sports quality for the sample search?

2. What is the nature of the relationship existing between the school environment and the quality of teaching physical education and sports at the educational institutions of the research sample?

\section{Methods}

2-1-Participant: The research sample included 71 of 102 professors or by 70\%, professor of physical education distribute at high schools in Mostaganem Province, for the academic year 2014/2015.

2-2- Statistical means: percentages, averages, standard deviation, Pearson correlation coefficient, Ka 2 test.

2-3- Variable Search Tools: In order to achieve the objectives of this study we build two questioner to measure research variables (school environment - quality of teaching)

1. Configuration sincerity premise manner internal consistency: the researcher using the configuration sincerity premise manner internal consistency on a sample scoping study strength of 22 professor of physical education in secondary education of Mostaganem state, where we calculate the expense of the correlation coefficient between each phrase and dimension to which it belongs, and the dimensions and axes to which they belong, and between each axis and the questionnaire as a whole, have the results of the analysis showed that all correlation coefficients were statistically significant only three phrases from each tool came is a function to be later removed from the instruments, ranging correlation coefficient for the tool own questionnaire to the school environment between 0.429 as the lowest value and 0.910 as the highest value, As for the second tool has ranged between 0.424 and 0.935 , the tool to become finalized carrying 41 words to form the school environment and 72 words to form the quality of teaching, and we have used in the analysis of the results and discharged Likert system triple to form the school environment and Quintet For the quality of teaching form.

2-4. The stability of the questionnaire: the researcher apply tools and re-applied with interval between the two phases was estimated at 10 days while maintaining the same variables (the same teachers, the same high school, same time) and that was a sample scoping study estimated at 22 professor, and the results of the two applications after statistical treatment calculates the Pearson correlation coefficient as follows: 
Table 1: Illustrates the coefficients of correlation of axes degree and total degree of tools and coefficient of stability

\begin{tabular}{|c|c|c|c|c|c|c|c|}
\hline $\begin{array}{l}\text { Statistical } \\
\text { study }\end{array}$ & questionner axes & $\begin{array}{l}\text { honesty } \\
\text { coefficient }\end{array}$ & $\begin{array}{l}\text { stability } \\
\text { coefficient }\end{array}$ & $\begin{array}{l}\text { sample } \\
\text { size }\end{array}$ & $\begin{array}{l}\mathrm{t} \\
\text { tabular }\end{array}$ & $\begin{array}{l}\text { degree } \\
\text { of } \\
\text { freedom }\end{array}$ & $\begin{array}{l}\text { statistical } \\
\text { significance } \\
\text { at the0.05 }\end{array}$ \\
\hline \multirow{3}{*}{$\begin{array}{c}\text { School } \\
\text { environment }\end{array}$} & school buildings & 0.91 & 0.84 & \multirow{6}{*}{22} & \multirow{6}{*}{0.423} & \multirow{6}{*}{20} & significant \\
\hline & Sports stadiums & 0.92 & 0.90 & & & & significant \\
\hline & $\begin{array}{c}\text { Means } \\
\text { pedagogical }\end{array}$ & 0.75 & 0.88 & & & & significant \\
\hline \multirow{3}{*}{$\begin{array}{l}\text { The quality } \\
\text { of teaching }\end{array}$} & Planning & 0.91 & 0.80 & & & & significant \\
\hline & Implementation & 0.93 & 0.83 & & & & significant \\
\hline & Evaluation & 0.71 & 0.82 & & & & significant \\
\hline
\end{tabular}

\section{Results}

3.1 What is the level quality of teaching physical education at of research sample average?

The first axis: Lesson planning

Table 2: shows the levels and frequencies, percentages and Ka 2 to the axis of the lesson planning

\begin{tabular}{|c|c|c|c|c|c|c|c|}
\hline Dimensions & Levels & Duplicates & $\begin{array}{c}\text { the } \\
\text { percentages }\end{array}$ & $\begin{array}{c}\mathrm{K} 2 \\
\text { calculated }\end{array}$ & $\begin{array}{c}\text { K2 } \\
\text { tabular }\end{array}$ & $\begin{array}{c}\text { degrees } \\
\text { of } \\
\text { freedom }\end{array}$ & $\begin{array}{c}\text { Statistical } \\
\text { significance } \\
\text { at } 0.01\end{array}$ \\
\hline \multirow{3}{*}{$\begin{array}{c}\text { lesson } \\
\text { preparation and } \\
\text { to identify its } \\
\text { goals }\end{array}$} & good & 24 & $\% 34$ & \multirow{3}{*}{28.92} & \multirow{6}{*}{09.21} & \multirow{6}{*}{02} & \multirow[t]{3}{*}{ significant } \\
\hline & average & 42 & $\% 59$ & & & & \\
\hline & Low & 05 & $\% 07$ & & & & \\
\hline \multirow{3}{*}{$\begin{array}{c}\text { preparation } \\
\text { pedagogical } \\
\text { methods and the } \\
\text { creation of } \\
\text { dedicated } \\
\text { teaching place }\end{array}$} & good & 41 & $\% 58$ & \multirow{3}{*}{31.21} & & & \multirow[t]{3}{*}{ significant } \\
\hline & average & 27 & $\% 38$ & & & & \\
\hline & Low & 03 & $\% 04$ & & & & \\
\hline \multirow{3}{*}{$\begin{array}{l}\text { determine the } \\
\text { characteristics of } \\
\text { the students and } \\
\text { their needs }\end{array}$} & good & 45 & $\% 63$ & \multirow{3}{*}{39.06} & & & \multirow[t]{3}{*}{ significant } \\
\hline & average & 24 & $\% 34$ & & & & \\
\hline & Low & 02 & $\% 03$ & & & & \\
\hline
\end{tabular}

The second axis: the quality of the implementation of the lesson:

Table 3: shows the levels and frequencies, percentages and Ka 2 to the axis of the implementation of the lesson

\begin{tabular}{|l|c|c|c|c|l|l|l|}
\hline Dimensions & levels & duplicates & $\begin{array}{l}\text { the } \\
\text { percentages }\end{array}$ & $\begin{array}{l}\text { K2 } \\
\text { calculated }\end{array}$ & $\begin{array}{l}\text { K2 } \\
\text { spreadsheet }\end{array}$ & $\begin{array}{l}\text { degrees } \\
\text { of } \\
\text { freedom }\end{array}$ & $\begin{array}{l}\text { Statistical } \\
\text { significance } \\
\text { at 0.01 }\end{array}$ \\
\hline \multirow{2}{*}{$\begin{array}{l}\text { a good show } \\
\text { and good } \\
\text { presentation } \\
\text { for the lesson }\end{array}$} & good & 19 & $\% 27$ & & & & Significant \\
\cline { 2 - 5 } & average & 48 & $\% 67$ & \multirow{2}{*}{42.27} & & \\
\cline { 2 - 5 } & Low & 04 & $\% 06$ & & & \\
\hline
\end{tabular}




\begin{tabular}{|c|c|c|c|c|c|c|c|}
\hline \multirow{3}{*}{$\begin{array}{l}\text { to encourage } \\
\text { good and to } \\
\text { raise } \\
\text { motivation to } \\
\text { learn }\end{array}$} & good & 37 & $\% 52$ & \multirow{3}{*}{30.28} & 9.21 & \multirow{12}{*}{02} & \multirow[t]{3}{*}{ Significant } \\
\hline & average & 32 & $\% 45$ & & & & \\
\hline & Low & 02 & $\% 03$ & & & & \\
\hline \multirow{3}{*}{$\begin{array}{l}\text { good use of } \\
\text { teaching } \\
\text { methods and } \\
\text { techniques } \\
\text { appropriate } \\
\end{array}$} & good & 17 & $\% 24$ & \multirow{3}{*}{51.50} & & & \multirow[t]{3}{*}{ Significant } \\
\hline & average & 51 & $\% 72$ & & & & \\
\hline & Low & 03 & $\% 04$ & & & & \\
\hline \multirow{3}{*}{$\begin{array}{l}\text { good use } \\
\text { pedagogical } \\
\text { methods and } \\
\text { technology } \\
\text { education }\end{array}$} & good & 28 & $\% 40$ & \multirow{3}{*}{30.11} & & & \multirow[t]{3}{*}{ Significant } \\
\hline & average & 40 & $\% 56$ & & & & \\
\hline & Low & 03 & $\% 04$ & & & & \\
\hline \multirow{3}{*}{$\begin{array}{l}\text { Section good } \\
\text { management } \\
\text { and control in } \\
\text { time }\end{array}$} & good & 33 & $\% 46$ & \multirow{3}{*}{32.91} & & & \multirow[t]{3}{*}{ Significant } \\
\hline & average & 37 & $\% 52$ & & & & \\
\hline & Low & 01 & $\% 02$ & & & & \\
\hline
\end{tabular}

The third axis: the quality of the lesson evaluation

Table 4: shows the levels and frequencies, percentages and Ka 2 to the axis of the lesson evaluation

\begin{tabular}{|c|c|c|c|c|c|c|c|c|}
\hline Axe & Levels & redundancy & $\begin{array}{c}\text { the } \\
\text { percentage }\end{array}$ & $\begin{array}{c}\text { Ka2 } \\
\text { calculated }\end{array}$ & $\begin{array}{c}\text { Ka2 } \\
\text { spreadsheet }\end{array}$ & $\begin{array}{c}\text { degree of } \\
\text { freedom }\end{array}$ & $\begin{array}{c}\text { level of } \\
\text { significance }\end{array}$ & $\begin{array}{c}\text { Statistical } \\
\text { significance } \\
\text { at the 0.05 }\end{array}$ \\
\hline $\begin{array}{c}\text { Lesson } \\
\text { Evaluation }\end{array}$ & good & 28 & 39 & 33.31 & 9.21 & 02 & 0.01 & Significant \\
\cline { 2 - 9 } & average & 41 & 58 & & & & & \\
\cline { 2 - 6 } & low & 02 & 03 & & & & \\
\hline
\end{tabular}

3-2 what is the nature of the relationship existing between the school environment and the quality of teaching physical education at the level of the educational institutions of the research sample?

Researcher deliberately make sure this relationship by calculating the Pearson correlation coefficient between the results of the forms, where the results were as follows

Table 5: shows the results of correlation between the school environment and the professors quality of teaching physical education

\begin{tabular}{|c|c|c|c|c|c|c|}
\hline Axes & $\begin{array}{l}\text { The value of the } \\
\text { correlation } \\
\text { coefficient between } \\
\text { the school } \\
\text { environment and } \\
\text { the quality of } \\
\text { teaching }\end{array}$ & $\begin{array}{c}\text { the } \\
\text { sample }\end{array}$ & $\begin{array}{l}\text { correlation } \\
\text { coefficient } \\
\text { "R" size of } \\
\text { table }\end{array}$ & $\begin{array}{l}\text { degree } \\
\text { of } \\
\text { freedom } \\
\mathrm{n}-2\end{array}$ & $\begin{array}{c}\text { relationship } \\
\text { type }\end{array}$ & $\begin{array}{l}\text { statistical } \\
\text { significance } \\
\text { at } 0.05\end{array}$ \\
\hline $\begin{array}{c}\text { School } \\
\text { environment } \\
\text { The quality } \\
\text { of teaching }\end{array}$ & 0.424 & 71 & 0.322 & 69 & positive & Significant \\
\hline
\end{tabular}




\section{Discussion}

Through results Entries in the tables No. (3), (4), (05) above, we conclude:

- That the majority of professors remains their performance use of the component layout lesson during the teaching process as good to moderate in some cases, where the majority of their answers for the benefit of the average degree regarding the preparation of the lesson and identify its goals and this by $59 \%$, with respect to the preparation of pedagogical methods and identify students characteristics and the analysis of their needs were most of their answers for the benefit of a good degree by $58 \% 63 \%$, respectively.

- The majority of professors remains their use performance element implementation of the lesson during the teaching process moderately, the data dump results have shown that the majority of their answers have not reached a good level, and signed within the intermediate level, for teaching practices represented by the following dimensions in descending order as follows: the use of roads and methods of teaching occasion, the good and the presentation of the study, the use of pedagogical methods and technology education, section management and control at the time, and this proportion $72.67 \% 0.56 \% 0.52 \%$ respectively, while given a greater percentage of answers professors after the promotion and raise the motivation of pupils to learn good degree of $52 \%$.

- The majority of professors remains their use for the Performing element Lesson evaluation moderately and large in some cases, the results showed that most of the answers professors of physical education and sports given the average degree and this by $58 \%$.

And for significant differences between the answers, the researcher used the Ka2 Test, reaching all Ka 2 values calculated for these axes greater than the tabular value estimated at 9.21 when the degree of freedom 2 and the level of significance 0.01 , and this means there is a statistically significant difference between the professors answers differences.

Based on the foregoing, it is clear to us that lesson planning component was the most exercise when professors of physical education and sports in terms of the level of performance so take its course towards good, compared to the two elements implementation and evaluation of the lesson, who were less exercise when education professors of physical and sporting terms of the level of performance which focused on degree average, and this guide the teachers answers, and it is to say that the level quality of teaching physical education and sports at secondary school from teachers point of view was average on the whole, they agree this result with the findings of a study (Kubaisi 2010 , p. 15), which referred to that there is a decline in the quality of teaching, and also agree in general features with the findings of each of the study (Taleb A. 2011, p. 184) which indicated that there is a lack of professor of physical education and sports competencies professional familiarity, and study (Osman, page 13) which indicated that a weakness in the performance of professors linked to the poverty of the physical environment, the consequent weakness in academic achievement.

Researcher attributed reason for this, perhaps to the lack of professor of physical education and sports of competencies professional familiarity and gestures which may be due to some teachers did not receive good education in their course of study, as well as perhaps the none means activation of modern technology in the process of teaching for some educational units that included its well going and the dependence on traditional teaching styles that are based on direct instruction, and not deferrals of teaching methods developed with the approach competencies which are based on problem-solving style programs, was also due to the failure to the teachers observe for individual differences among students and the lack of interest in providing feedback to them, and not following evaluation methods which are based on self-evaluation of students, lack of diversification in the media evaluation overall between applied and theoretical exams, was also due to the poor school environment conditions and climate in high school that suffer from a lack of financial means and of the lack of means, equipment, sports stadiums, as well as the lack of news article from books and magazines in the field of specialization, as we pointed out above, in addition to time devoted to the subject of physical education and sports, which offset overcrowding in the number of pupils at the district level probably inadequate for the use of a professor of physical education and sports some of the alternatives available from the activities and strategies of evaluation teaching and means through share time, not to mention the lack of inspectors of physical education and sports, which affects negatively on the quality of the teaching of physical education and sports, whether guiding visits or training sessions that can be a major supportive extends to professor of physical education and sports of all that is new about this activity, and 
improves their modern teaching techniques, it was also due to the low level of job satisfaction resulting perhaps from low salaries and lack of incentives for promotions system as evidenced by the entry in strikes during this school year.

Through the reading of the results recorded in the table (6) above it's clear to us the following:

- The "R." correlation coefficient between the school environment and the quality of teaching physical education and sports was 0.424 , largest of the tabular value of the estimated value of 0.232 at a degree of freedom 69 and the significance level 0.05, this means the presence of relational positive statistically significant relationship between the school environment and the quality of teaching physical education and sports, and so the researcher explains that the more appropriate and effective school environment include all material components of typical buildings and stadiums and arenas, sports halls and pedagogical means and toilets, as well as lighting and ventilation, and various other sources of learning, to achieve quality of teaching physical education and sports, in the sense that the school environment It has a direct impact on professor teaching practice of physical education and sports, so as to facilitate his employ all of his knowledge, information and competencies process both been associated with, including planning, implementation, and evaluation of the lesson or other necessary skills that make it able to provide quality education distinguished by greater use of playgrounds and means, organizing more care and precision of lessons, feedback more specifically, the diversity of the largest and follow the best of the activities, a greater ability to analyze student needs, higher than the activity and the amount allocated to the learning educational time levels, the economy in time and effort, use of more than one way and style of teaching, and this is what we recognize the fact that the teaching of physical education and sports quality with Professor mainly depend on the appropriate school environment material surrounding it, and this result consistent came with what indicated by each of the study (Sheikh 2011, p. 13) that the quality of teaching influenced by all the school environment elements , and as far as the quality requirements in each of these factors is available to the extent that the quality of teaching, and study (Al-mokrin 2005, p. 6) which indicated through which many researchers and those interested in education confirmed in experimental studies on the effect of the physical school environment through the school building to the collection school pupils on the one hand, and on the performance of the teacher with respect to the employment of teaching methods, and their interaction with the students on the other hand as the study of (Martin, 2002), also confirms the results of a study (Ayoub 2008, p. 181) to provide various physical capabilities of hardware and sports equipment and tools and means of pedagogy in terms of quantity and quality, helping professor of physical education and sports to create the right pedagogical atmosphere for the implementation and completion of the various phases of the courses, and facilitate his educational conduct quotas and the application of the various stages of the study plan in the selected time process and more effectively by controlling the teaching positions for pupils and thus achieve educational goals ruler in the program for physical education and sports, and adds in the same context (Tantawi 2011, p. 116) that the educational method used by the teacher to improve teaching and raise the effectiveness and deepen the degree of learners take advantage of it.

\section{Conclusion}

The quality of the teaching of physical education at the level of the average for the whole sample at the level of high schools in Mostaganem state, as we have drawn that there is relational positive statistically significant relationship between the school environment and the quality of teaching physical education.

\section{References:}

1. Allali Taleb. (2011). Knowledge of physical education and sports teacher at the secondary education professional competencies in light of changes in the Program from the standpoint of (teachers and mentors), Institute of Physical Education and Sports, Mostaganem, Algeria.

2. Amel Bent Mohammed Ali Abdullah Alchatli. (2010). The impact of the school environment in the development of creative values Fine art education at the secondary level from the viewpoint of female teachers, College of Education, Umm Al Qura University, Saudi Arabia. 
3. Amine Anwar al-Kholi. (1996). Physical assets of professional sports education, vocational and academic system setup, Dar Al-fikr Arabi, Cairo, Egypt.

4. Bassiouni Mahmoud Awad, Faisal Yassin Shati. (1992). Theories and methods of physical education, Office of University Publications, Algeria.

5. Benguenab Hadj, Bouloufa Boujemaa, Chenati Ahmed. (2008). Obstacles of positive Subscribe studied in physical education and sports at the high school students in the scientific journal Mostaganem number VII in December 2010 Physical Education and Sports Institute, University of Mostaganem.

6. Bushra bent Khalaf Anzi. (2007). The development of teacher competences in the light of the quality standards in public education. Saudi Arabia: study submitted to the fourteenth annual meeting of the Saudi Society for Educational and Psychological Science entitled "Quality in Education", 15-16 Mai.

7. Chebl Badran, Saeed Suleiman. (2009). The third millennium teacher in the context of the quality of professional practice standards, The new University House, Alexandria, Egypt. Jordan.

8. Effat Mustafa Tnawi. (2011). Effective teaching -Planning-skills-Strategies-. Amman -

9. Hiba Farouk Nawar, Fatima Sheikh. (2011). Quality in university teaching. The first quality and development Forum, University of J azan, Saudi Arabia. 